\title{
PENGARUH REBUSAN DAUN SALAM TERHADAP PENURUNAN TEKANAN DARAH PADA LANSIA PENDERITA HIPERTENSI DI WISMA SERUNI UPT PSLU JEMBER
}

\author{
Susi Wahyuning Asih \\ Program Studi S1 Keperawatan Fakultas Ilmu KesehatanUniversitas Muhammadiyah Jember \\ *e-mail: susiwahyuningasih@ymail.com
}

\begin{abstract}
ABSTRAK
Hipertensi merupakan salah satu bentuk penyakit kronis pada lansia. Perubahan fisiologis pada lansia mengindikasikan perlunya pendekatan lain untuk menangani hipertensi, seperti dengan menggunakan terapi herbal. Salah satu bentuk terapi herbal yang dapat digunakan untuk mengatasi hipertensi adalah daun salam. Tujuan penelitian ini adalah untuk mengetahui pengaruh daun salam terhadap penuruan tekanan darah pada lansia dengan hipertensi di UPT PSTW Jember. Penelitian ini adalah penelitian pre eksperimental dengan pendekatan one group pre post test design. Populasi dalam penelitian ini adalah seluruh lansia dengan hipertensi yang tinggal di UPT PSTW Jember sejumlah 45 orang. Responden diambil dengan teknik total sampling. Responden diberi air rebusan daun salam sebanyak 1 gelas, dua kali sehari selama 2 minggu. Tekanan darah responden diukur dengan menggunakan sphygmomanometer. Analisis statistik menunjukkan uji t test untuk tekanan darah sistolik adalah 0,000 dan 0,087 untuk tekanan darah diastolik. Sehingga dapat disimpulkan bahwa air rebusan daun salam berpengaruh terhadap penurunan tekanan darah sistolik dan tidak berpengaruh terhadap penurunan tekanan darah diastolik lansia dengan hipertensi. Oleh karenanya, daun salam dapat digunakan sebagai salah satu terapi herbal untuk menurunkan tekanan darah pada lansia dengan hipertensi.

Kata kunci : lansia, hipertensi, daun salam
\end{abstract}

\section{ABSTRACT}

Hypertension is one of chronic disease of elderly. Physiological changes in elderly indicated the need of other approach to cure hypertension, such as the use of herbal theraphy. One of herbal theraphy that can be use to cure hypertension is Syzygiantum Polyanthum. This study is conduct to find out the effectiveness of Syzygiantum Polyanthum to decrease blood pressure in elderly with hypertension. It's a pre experimental study with one group pre post test design. The population are elderly with hypertension who lived in PSTW Jember counted 45 elderly. The respondents are taken by total sampling. The respondents was given a glass of boiled water of Syzygiantum Polyanthum, twice a day for two weeks. The blood pressure was measured by using sphygmomanometer. Statistical analysis using paired t test show $p$ value 0,000 for sistolic blood pressure and 0,087 for diastolic blood pressure. It can be conclude that the boiled water of Syzygiantum Polyanthum are efferctive to decrease the sistolic blood pressure but not effective to decrease the diastolic blood pressure in elderly with hypertension.

Key words : elderly, hypertension, Syzygiantum Polyanthum

\section{PENDAHULUAN}

Penuaan merupakan hal normal yang terjadi pada setiap orang (Stanley, 2007). Menua adalah suatu proses menghilangnya secara perlahan - lahan kemampuan jaringan untuk memperbaiki diri dan mempertahankan struktur dan fungsi normalnya sehingga tidak dapat bertahan tehadap infeksi dan memperbaiki kerusakan fungsi yang diderita 
(Constantindes, 1994 dalam dazpecta, 2012). Hipertensi seringkali disebut sebagai pembunuh gelap (silent killer), karena termasuk penyakit yang mematikan, tanpa disertai dengan gejalagejalanya lebih dahulu sebagai peringatan bagi korbannya. Kalaupun muncul, gejala tersebut seringkali dianggap gangguan biasa, sehingga korbannya terlambat menyadari akan datangnya penyakit (Sustrani, 2006).

Hipertensi pada lanjut usia sebagian besar merupakan hipertensi sistolik terisolasi (HST), meningkatnya tekanan sistolik menyebabkan besarnya kemungkinan timbulnya kejadian stroke dan infark myocard bahkan walaupun tekanan diastoliknya dalam batas normal (isolated systolic hypertension). Isolated systolic hypertension adalah bentuk hipertensi yang paling sering terjadi pada lansia. Pada suatu penelitian, hipertensi menempati $87 \%$ kasus pada orang yang berumur 50 sampai 59 tahun. Adanya hipertensi, baik HST maupun kombinasi sistolik dan diastolik merupakan faktor risiko morbiditas dan mortalitas untuk orang lanjut usia. Hipertensi masih merupakan faktor risiko utama untuk stroke, gagal jantung penyakit koroner, dimana peranannya diperkirakan lebih besar dibandingkan pada orang yang lebih muda (Kuswardhani, 2007).

Berbagai cara dapat dilakukan untuk mengurangi nyeri dari gejala yang ditimbulkan, salah satunya adalah dengan menggunakan terapi herbal seperti daun salam. Daun salam merupakan salah satu daun yang biasa digunakan oleh para Ibu rumah tangga untuk penyedap dan pengharum masakan. Manfaat daun salam tidak hanya digunakan untuk menambah cita rasa pada masakan saja, namun juga dapat dijadikan obat tradisional mencegah sekaligus menyembuhkan beberapa penyakit yang ada di tubuh. Kandungan vitamin dan mineral yang ada pada daun salam sangat baik untuk kesehatan tubuh. Daun salam untuk obat herbal ini sudah dikenal sejak dulu, namun sayangnya belum terkenal seperti obat herbal lainnya

Berdasarkan studi pendahuluan yang dilakukan di UPT PSTW Jember pada tanggal 28 Maret 2018, didapatkan data jumlah lansia yang tinggal diwisma seruni berjumlah 15 orang, 4 diantaranya lansia perempuan dan 11 orang laki - laki. Diketahui dari hasil pemeriksaan kesehatan, bahwa terdapat 9 lansia yang tinggal di wisma seruni memiliki tekanan darah cukup tinggi. Hasil wawancara dengan 9 orang lansia yang mengalami hipertensi diketahui 2 (20\%) diantaranya rutin memmeriksakan diri dan peduli terhadap kesehatan, sedangkan 6 lansia lainnya peduli terhadap kesehatan akan dirinya masih kurang.Tujuan penelitian ini adalah untuk mengidentifikasi efektifitas rebusan daun salam terhadap hipertensi pada lansia di UPT PSTW Jember.

\section{METODE}

Desain penelitian yang digunakan adalah pre experimental dengan pendekatan one group pre-post test design, yaitu mengungkapkan hubungan sebab akibat dengan cara melibatkan satu kelompok subjek. Populasi dalam penelitian ini adalah 45 lansia penderita hipertensi di UPT PSLU Jember dengan teknik total sampling seluruh populasi dijadikan sampel penelitian.

Responden diberikan minuman air rebusan daun salam sebanyak 1 gelas dua kali sehari selama 2 minggu. Tekanan darah diukur sebelum dan setelah tindakan. Data selanjutnya diolah dengan uji $t$ berpasangan untuk mengetahui pengaruh air rebusan daun salam dalam menurunkan tekanan darah lansia dengan hipertensi.

HASIL

Tabel 1. Karakteristik Umum Responden

\begin{tabular}{|c|c|c|}
\hline \multirow{2}{*}{$\begin{array}{l}\text { Karakteristik } \\
\text { Usia }\end{array}$} & $\mathrm{n}$ & $\%$ \\
\hline & & \\
\hline $60-69$ & 5 & 11,2 \\
\hline $70-79$ & 20 & 44,4 \\
\hline $80-89$ & 20 & 44,4 \\
\hline
\end{tabular}


Tingkat Pendidikan

$\begin{array}{lll}\text { SD } & 10 & 22,2 \\ \text { SMP } & 15 & 33,3 \\ \text { SMA } & 20 & 44,4\end{array}$

Jenis Kelamin

\begin{tabular}{cll} 
Laki - laki & 40 & 88,9 \\
Perempuan & 5 & 11,2 \\
\hline Jumlah & 45 & 100 \\
\hline
\end{tabular}

Berdasarkan data pada tabel 1 dapat dilihat bahwa mayoritas responden berusia 70 - 79 tahun dan $80-89$ tahun, dengan tingkat pendidikan SMA dan berjenis kelamin laki - laki.

Tabel 2. Tekanan Darah Responden Sebelum dan Setelah Tindakan

\begin{tabular}{cccc}
\hline Variabel & Mean & $\begin{array}{c}\text { Std. } \\
\text { deviasi }\end{array}$ & $\begin{array}{c}\text { P } \\
\text { value }\end{array}$ \\
\hline Sistolik pre & 154,444 & \pm \\
& & 18,104 \\
Sistolik post & 140,00 & $\begin{array}{c} \pm \\
\end{array}$ & 0,000 \\
& & 15,811 & \\
& & 39 & \\
Distolik pre & 90,00 & \pm & \\
& & 7,0710 & \\
Siastolik post & 75,555 & \pm & 0,087 \\
& & \multicolumn{3}{c}{8,8191} \\
& & 7 & \\
\hline
\end{tabular}

Berdasarkan tabel 2 dapat diketahui bahwa terdapat perubahan rerata tekanan darah sistolik responden dari 154,444 $\mathrm{mmHg}$ sebelum diberi minum air rebusan daun salam menjadi $140 \mathrm{mmHg}$ setelah dilakukann. Uji $\mathrm{t}$ berpasangan menunjukkan $p$ value 0,000 yang artinya HO ditolak dengan kata lain air rebusan daun salam berpengaruh dalam menurunkan tekanan darah sistolik lansia dengan hipertensi. Sedangkan rerata tekanan darah diastolik sebelum dilakukan tindakan adalah $90 \mathrm{mmHg}$ menjadi 75,55 $\mathrm{mmHg}$ setelah dilakukan tindakan. Uji t berpasangan menunjukkan $\mathrm{p}$ value 0,087 lebih besar dari $\alpha$ 0,05 yang berarti $\mathrm{H} 0$ diterima, atau air rebusan daun salam tidak berpengaruh terhadap penurunan tekanan darah diastolik lansia dengan hipertensi.

\section{PEMBAHASAN}

Secara fisiologis pada lansia terjadi peningkatan kekakuan areteri besar yang berkontribusi terhadap terjadinya peningkatan tekanan darah sistolik (Pinto, 2007). Kekakuan arteri, disregulasi otonom dan proses menua pada ginjal berperan dalam patofisiologi terjadinya hipertensi pada lansia. Pada golongan usia yang lebih muda, laki - laki cenderung mengidap hipertensi dibandingkan perempuan karena perempuan memiliki estrogen sebagai pelindung dari resiko penyakit kardiovaskuler. Namun sejalan dengan peningkatan usia dan memasuki usia menopouse maka kemungkinan perempuan dan laki-laki untuk mengidap hipertensi adalah sama.

Daun salam dapat menurunkan kadar trigliserida serum karena daun salam mengandung beberapa senyawa seperti saponin, flavonoid, tanin dan niasin. Flavonoid dalam daun salam berfungsi sebagai antioksidan yang mampu mencegah terjadinya oksidasi sel tubuh. Semakin tinggi oksidasi semakin tinggi prevalensi terjadinya penyakit degeneratif, jadi kandungan flavonoid daun salam dapat mencegah terjadinya hipertensi dan menurunkan kolesterol darah. Tanin berfungsi sebagai antioksidan dan hipokolesterolemia. Tanin bekerja dengan cara bereaksi dengan protein mukosa dan sel epitel usus sehingga menghambat penyerapan lemak. Saponin yang berfungsi mengikat kolesterol dengan asam empedu sehingga dapat menurunkan kadar kolesterol.

Kandungan dalam daun salam menstimulasi penurunan kolesterol dalam darah, sehingga membantu mempertahankan elastisitas pembuluh darah. Terbukti dengan adanya penurunan rerata tekanan darah sistolik responden dari 154,44 mmHg menjadi $140 \mathrm{mmHg}$. 
Park et al (2015) menyebutkan bahwa tekanan diastolik menggambarkan penutupan katup aorta, besaran energi pada serat elastik arteri besar selama sistolik dan tahanan aliran darah dalam arteriol hingga kapiler. Penutupan katup aorta saat diastol dan daya recoil serat elastis aorta dan arteri besar mengatur aliran darah, meski saat jantung dalam kondisi relaksasi. Pinto (2007) berpendapat bahwa tahanan vaskuler perifer bertanggung jawab pada peningkatan tekanan diastolik, terutama pada lansia. Peningkatan tahanan vaskuler perifer dapat dipengaruhi oleh penurunan elastisitas arteri. Hasil penelitian menunjukkan adanya perubahan rerata tekanan darah diastolik responden dari 90 $\mathrm{mmHg}$ menjadi $75 \mathrm{mmHg}$ namun hasil uji $\mathrm{t}$ berpasangan menujukkan $\mathrm{p}$ value 0,087 yang berarti tidak ada pengaruh air rebusan daun salam terhadap perubahan tekanan darah diastolik responden. Hal ini sesuai dengan pendapat Pestana (2015) yang menyebutkan bahwa secara fisiologis akibat proses menua pada sistem kardiovaskuler disebutkan bahwa pada lansia yang berusia di atas 60 tahun tekanan diastolik akan mengalami sedikit perubahan atau bahkan menetap.

\section{KESIMPULAN}

Hasil penelitian ini menyimpulkan bahwa lain air rebusan daun salam berpengaruh dalam menurunkan tekanan darah sistolik lansia dengan hipertensi namun tidak berpengaruh terhadap penurunan tekanan darah diastolik lansia dengan hipertensi.

\section{SARAN}

Peneliti menyarankan agar lansia dengan hipertensi dapat mengaplikasikan penggunaan daun salam sebagai salah satu bentuk terapi herbal untuk menangani hipertensi, khususnya pada lansia

\section{KEPUSTAKAAN}

Agus, P. 2000, Kedaruratan Medik:

Pedoman Penatalaksanaan Praktis, Binarupa Aksara, Jakarta.
Arikunto, S. 2010. Prosedur penelitian: Suatu Pendekatan Praktik.(Edisi Revisi). Jakarta: Rineka Cipta

Bustan. 2007. Epidemiologi Penyakit Tidak Menular. Jakarta: Rineka Cipta

Cahyono, S. 2008. Gaya Hidup dan Penyakit Modern. Yogyakarta: Kanisius

Departemen Kesehatan RI. 2012. Pharmaceutical Care untuk Penyakit Hipertensi. Jakarta: Departemen Kesehatan RI.

Evelyn, C.P. 1999, Anatomi dan Fisiologi Untuk Paramedis, Penerbit PT Gramedia, Jakarta.

Fauzi. I. 2014. Buku Pintar Deteksi Dini Gejala dan Pengobatan Asam Urat, Diabetes dan Hipertensi.

Yogyakarta: Araska.

Junaedi, E. 2013. Hipertensi Kandas

Berkat Herbal. Jakarta Selatan

Kristanti, H. 2013. Mencegah dan Mengobati 11 Penyakit Kronis. Citra Pustaka: Yogyakarta.

Ni Kadek, et al. 2014. Pengaruh Kombinasi Jus Seledri, Wortel dan Madu Terhadap Hipertensi Di Wilayah Kerja Puskesmas II Denpasar Barat. Artikel Penelitian, Stikes Bina Husada

Nugroho, W. 2010. Keperawatan Gerontik dan Geriatrik. Jakarta: EGC.

Nursalam.2009. Konsep dan Penerapan Metodologi Penelitian Ilmu Keperawatan. Pedoman Skripsi, Tesis dan Instrumen Penelitian

Notoatmodjo, S. 2010. Metode Penelitian Kesehatan. Jakarta:Rineka Cipta.

Patricia, GM., et.al. 2011. Keperawatan

Kritis: pendekatan asuhan holistic ed.8; alih bahasa, Nike Esty wahyuningsih. Jakarta: EGC

Parker, M. \& Smith, M., 2010. Nursing Theories and Nursing Practice. Philadelphia: F A Davis Company.

Park, J. B., Kario, K. \& Wang, J. G., 2015 Systolic Hypertension: An Increasing in Clinical Challenge in 
Asia. Hypertension Research, 5(38), pp. 227 - 236.

Pestana, M., 2002. Hypertension in Elderly. International Urology and Nephrology, Volume 3, pp. 563 569. 